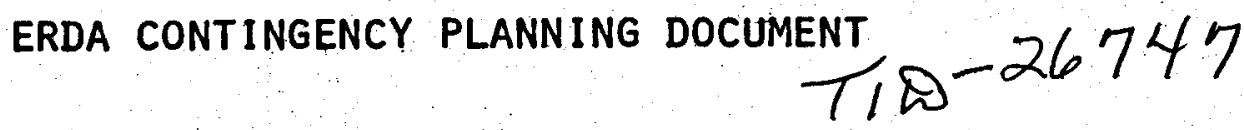

RESEARCH AND DEVELOPMENT

ASSIGNED TO THE ASSISTANT ADMINISTRATOR FOR

SOLAR, GEOTHERMAL, AND

ADVANCED ENERGY SYSTEMS

\title{
GEOTHERMAL ENERGY
}

SGA-2

NOVEMBER 11,1974

PREPARED BY ATOMIC ENERGY COMMISSION

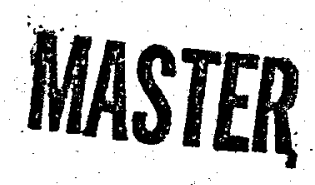




\section{DISCLAIMER}

This report was prepared as an account of work sponsored by an agency of the United States Government. Neither the United States Government nor any agency Thereof, nor any of their employees, makes any warranty, express or implied, or assumes any legal liability or responsibility for the accuracy, completeness, or usefulness of any information, apparatus, product, or process disclosed, or represents that its use would not infringe privately owned rights. Reference herein to any specific commercial product, process, or service by trade name, trademark, manufacturer, or otherwise does not necessarily constitute or imply its endorsement, recommendation, or favoring by the United States Government or any agency thereof. The views and opinions of authors expressed herein do not necessarily state or reflect those of the United States Government or any agency thereof. 


\section{DISCLAIMER}

Portions of this document may be illegible in electronic image products. Images are produced from the best available original document. 


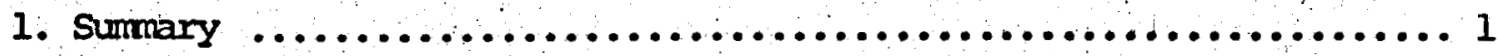

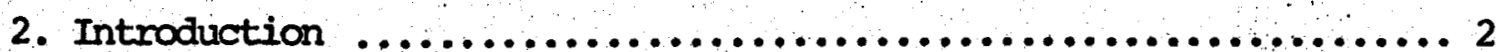

2.1 The Geothermal Resource $\ldots \ldots \ldots \ldots \ldots \ldots \ldots \ldots \ldots \ldots \ldots \ldots \ldots \ldots$

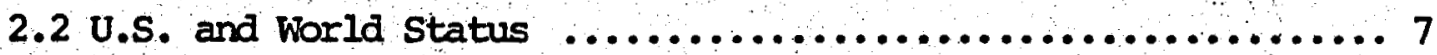

2.3 Rationale for Geothermal Program .................... 9

2.4 General objectives . ............................11

3. ERDA Geothermal Program $\ldots \ldots \ldots \ldots \ldots \ldots \ldots \ldots \ldots \ldots \ldots \ldots \ldots \ldots \ldots \ldots \ldots \ldots \ldots$

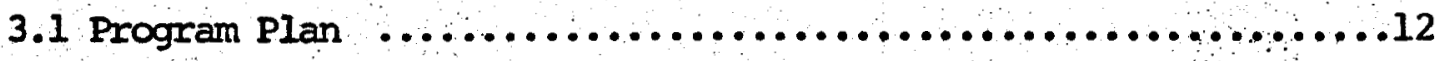

3.2 Technologies to be Investigated $\ldots \ldots \ldots \ldots \ldots \ldots \ldots \ldots \ldots \ldots 12$

3.3 Timing and Pace of Develogment .........................

4. Program Implementation $\mathrm{Plan} \quad \ldots \ldots \ldots \ldots \ldots \ldots \ldots \ldots \ldots \ldots \ldots \ldots \ldots \ldots \ldots$

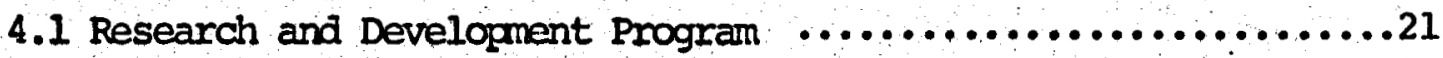

4.2 Detailed Program objectives $\ldots \ldots \ldots \ldots \ldots \ldots \ldots \ldots \ldots \ldots \ldots \ldots \ldots 21$

4.3 Detailed Program, Schedules and Milestones $\ldots \ldots \ldots \ldots \ldots \ldots \ldots . \ldots \ldots$

4.4 Interfaces with other Agencies $\ldots \ldots \ldots \ldots \ldots \ldots \ldots \ldots \ldots \ldots \ldots 42$

5. Funding $\ldots \ldots \ldots \ldots \ldots \ldots \ldots \ldots \ldots \ldots \ldots \ldots \ldots \ldots \ldots \ldots \ldots \ldots \ldots \ldots \ldots \ldots 44$

5.1 ERDA Budget $\ldots \ldots \ldots \ldots \ldots \ldots \ldots \ldots \ldots \ldots \ldots \ldots \ldots \ldots \ldots \ldots \ldots \ldots 44$

This report was prepared as an account of work

sponsored by the United States Government. Neither

the United States nor the United States Energy

Research and Development Administration, nor any of

their employees, nor any of their contractors,

subcontractors, or their employees, makes any

warranty, express or implied, or assumes any legal

Hability or responsibility for the accuracy, completeness

or usefulness of any information, apparatus, product or

process disclosed, or represents that its use would not

infringe privately owned rights. 


\section{EXECUITVE SUMMARY}

Geothermal Energy Program

Responsible Cadre Member

Principal supporting Iaboratories
L. B. Werner - AEC

IBL - P. Witherspoon

IIL - R. Austin

IASI- J. ROwley

INEI- J. Kunze

\section{Program Scope}

The ERDA geothermal energy program is a comprehensive effort, in conjunction with industry, to aid in develogment of the nation's geothemal resources for the production of electricity and utilization of heat for other applications. It provides for development of six defined resource types, with specific plans for four pilot plants to prove the feasibility of utilizing this heat in an econamical. and environmentally acceptable manner. Utilizing the scientific and technical capabilities of our National laboratories, technology will be developed, with industry participation, and transferred to the public domain as an incentive for future commercial exploitation of this country's geothermal resources. A concurrent program of advanced research and technology will involve universities, industrial research facilities and National laboratories in solving technical problens inhibiting full commercial utilization of this energy source. Budget Sumary (\$ in mililions)

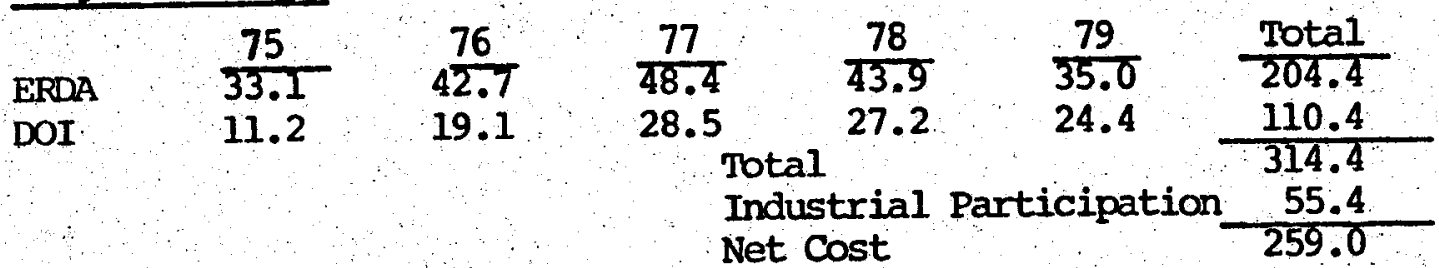




\section{Introduction}

The world's total production of electrical power from geothermal sources is about $1000 \mathrm{MW}$ of which $400 \mathrm{MW}$ is in the United States. The slow pace of development in the U.S. cannot be attributed to lack of resources since in various parts of the U.S. there exist vast quantities of geothermal energy in various forms. It is believed that these resources, although not precisely known, are adequate to supply a significant fraction of the total national electrical power requirements and heating needs. Exploitation of geothermal energy has been limited by legal and institutional problems and in some cases by technological difficulties. The research and development program described herein is designed to provide information relating to all of these problems, but is primarily concerned with demonstrating the technological feasibility of utilizing geothermal resources both economically and in an environmentally acceptable manner. The program is concerned with demonstrating the size and usefulness of geothermal resources as well as developing the technology necessary to utilize them. If vigorously pursued, the program can reasonably be expected to contribute to meeting both long and short range national energy needs. 


\subsection{The Geothermal Resource}

Geothermal Resources may be classified into four basic types.

- vapor dominated hydrothermal convective systems, i.e. dry steam;

- Iiquid-dominated hydrothermal convective systems;

- hydrothermal systems in geopressured sedimentary basins;

- hot dry rock;

To these coild be added nomal heat gradient formations and magma although these resources are believed to offer only very long range develogment prospects.

These types are listed in decreasing order of ease of development and estimated increasing order of size of the resource. The technology for utilization of dry steam systems is well developed but the resources in the U.S. are generally believed to be relatively scarce, perhaps sufficient to provide on the order of 15,000 megawatt-centuries of electricity 1 /, but more conservatively, a fraction of this amount. Hot water systems have been estimated to be at least 20 times as abundant

1/ Assessment of Geothermal Energy Resources - Prepared for the Committee on Energy Research and Development Goals, Federal Council for Science and Technology, Panel on Geothermal Energy Resources, Dallas I. Peck, Coordinator, Dept. of the Interior Sept. 25, 1972 . 
as dry steam systems $1 /$, and might provide as much as 200,000 megawatt-centuries of electricity $2 /$. Quantitative estimates of the potential capacity of geopressured basins have not been made but these resources are known to extend over very large geographical areas along the northern coast of the Gulf of Mexico as well as elsewhere in the world. Dry hot rock may ultimately prove to be the largest geothermal resource lother than normal gradient formations). The feasibility of extraction of useful heat from hot rock systems, however, has yet to be established, but estimates suggest sufficient recoverable thermal energy to provide many millions of megawatt centuries of electricity $2 /$ The inability to estimate more precisely each of these resources illustrates the need for further exploration as well as for development of technological data upon which utilization estimates can be based.

1/ The Potential for Energy Production from Geothermal Resources - Report of the Subcommittee on water and Power Resources, Committee on Interior and Insular Affairs, page 12, December 1973.

2/ Assessment of Geothermal Energy Resources - Prepared for the Committee on Energy Research and Development Goals, Federal Council for Science and Technology Panel on Geothermal Energy Resources, Dallas L, Peck, Coordinator, Dept. of the Interior Sept. 25, 1972 . 
The selection of resources to be investigated in the geothermal program thus represents a spectrum from the most easily developed (high temperature, low salinity liquid dominated systems) to the most difficult (hot dry rock). The potential for long range, large scale development is greatest for hot dry rock, but the prospect for immediate contributions to energy needs, at least R\&D cost, is greatest for the liquid systems. Dry steam systems are not deemed to justify additional federal R\&D investment because of the already advanced state of industrial development. Practical utilization of energy from magma cannot be anticipated before further basic research studies are performed to better define the potential resource and feasibility of developing materials and technology which would be needed for such systems. Normal gradient formations are not considered to be economical sources of energy due to high costs of drilling to great depths in order to reach useful temperatures. An exception may be slightly elevated or "near-nomal" heat gradient formations which could be reached at lesser depths and used to provide low grade heat for non-electric purposes. The high tenperature $\left(230^{\circ} \mathrm{C}\right)$ brines known to exist in the Imperial valley, California in very large quantities are typically highly saline $(20,000$ to $300,000 \mathrm{ppm})$. There are also regions 
in the U.S. where brines at moderate to high temperatures $\left(180-230^{\circ} \mathrm{C}\right)$ exist, which are of low salinity (less than $20,000 \mathrm{ppm})$.

Some of these resources which could be utilized for production of electrical power are situated near large population centers which are now dependent on oil and natural gas for electrical generation. Hence, eariy demonstration of reliable, economic systems for electric generation from these resources can have a significant national impact. Commercialization of these resources will make available to other regions oil and gas which otherwise would have been burned in Western power plants.

Low temperature (less than $150^{\circ} \mathrm{C}$ ) waters which are usually of very low salinity, are thought to be very widely distributed. These waters are potentially useful for agricultural applications, industrial process heat, space heating, and cooling, as well as other applications. There are geographical areas where a need for all these applications exist, hence, there may be need for total energy utilization systems designed to match this regional need. Such concepts could also be applied to the deposits of high temperature waters where the combination of electric power aeneration, mineral recovery and provision of process heat to industry 
may be an effective means of generally improving economics and reducing demand for oil and gas for these applications. Geopressured deposits of low temperature waters exist particularly along the Gulf Coast, a region of concentrated industrial activity. Applications here may consist of both electrical generation and process or space heating and cooling.

of particular significance is the ultimate potential of energy stored in hot dry rock. There are known areas such as in New Mexico where hot and apparently impermeable rock is reasonable close to the surface. The basic problem is to recover the energy stored in this rock. Once done, any one or a combination of the conversion systems could be applied at the surface. Hence, demonstration of utilization of this resource will emphasize establishing a reliable method for recovery of heat. Use of the energy so obtained could consist of electrical power production as well as other applications.

\subsection{The U.S. and World Status}

Currently, ary steam is used commercially for electrical generation in the U.S., Japan and Italy. High temperature 
low salinity brines are used for electrical production in New Zealand and Mexico. Low temperature low salinity brines are used for electrical power generation in the U.S.S.R. and for space heating or other non-electrical uses, principally in Japan, Iceland, Hungary and on a small scale in the U.S.

World geothermal electrical generating capacities are about as follows:

Italy - $400 \mathrm{MW}(\mathrm{e}) ; \mathrm{U} . \mathrm{S} .-400 \mathrm{MW}(\mathrm{e})$; New Zealand - $200 \mathrm{MW}(\mathrm{e})$ Mexico - 75 MW(e); Japan - 30 MW(e); and U.S.S.R. - 6 IW (e) Expansion of geothermal generating capacity is planned or underway in all, of these countries as well as in El Salvador and the Philippines. Exploration projects have been conducted in at least 10 other countries, and interest expressed by perhaps another 30 countries. At the Geysers, California it is planned to add about $100 \mathrm{MW}(\mathrm{e})$ per year for several years. This is the only location where such plans have been announced. However, acceleration of this schedule at least seems possible now thet the program for leasing federal land is underway. Lease sales have recently been held in several areas. In California three known Geothermal Resource Areas (K.G.R.A.) 
in the Geysers area, Mono-Long Valley and East Mesa were put up for bid. Many of the units offered in Iong Valley and East Mesa, both liquid daminated systems, recelved no bids. These facts might be construed to indicate a - relatively low level of interest by industry in moving rapidiy to exploit liquid daminated systems. There are, however, several proposed industrial development programs which are planned to lead to construction and operation of prototype electric generating plants in Imperial valley and in Central California and possibly New Mexico.

\subsection{Rationale for Geothermal Program}

The ERDA Geothermal Program is concerned with resolving, at the earliest practical time, the problems which currently inhibit the private sector from fully exploiting the Nation's reserves of geothermal energy. Accomplishment of this abjective could readily be achieved through an exclusive Government role in all phases fram resource exploration to commercial scale. However, the strategy adopted for the development of geothermal resources is based upan short-term government involvement with the small, but active geothermal industry. The private sector is expected to assume a major role - and greater degrees of risk - when the research phase begins to show that geothermal energy is a viable and long-term source of power. 
The ERDA program, in addition, is based upon early involvement by the private sector. Early participation would enable industry to acquire patent rights and proprietary data needed to maintain a campetitive. posture. A continuing but long-term Govermment role would minimize opportunities by individual companies to acquire exclusive rights since the results of Federally-financed research will be made available equally to all potential users. Thus, the program is structured to encourage industry to "take over" the entire program or phases of the effort at any , time it demonstrates a willingness and capability to utilize geothermal resources for the production of electricity and other purposes.

The geothermal development program is based on the premise that there exists in the U.S. an energy problem which will grow in magnitude unless constructive action is taken. This action should include realizing rapid commercialization of non-fossil energy sources such as qeothermal for both electrical generation and non-electrical uses.

Since dry steam reservoirs are limited and the technology is well developed, it is concluded that hot water systems should provide the next increment of energy supply in the near term. Hot water systems therefore should receive inmediate attention, particularly with respect to reservoir characterization to demonstrate reliability over long-tem production and a vigorous energy conversion development program. For the very long range, utilization of the hot ary rock resource will be important but will depend on development of the necessary energy extraction and conversion techniques. 


\subsection{General Ojectives}

- With the exception of dry steam, development of all geothermal resources has been lagging in the U.S. Although the solution of non-technological

problems is recognized as an important aspect of acceleration of the national geothermal development program, the primary goal of the ERDA program is to carry out the technical R\&D necessary to demonstrate that all of our geothermal resource forms can be economically utilized in an environmentally acceptable manner in time to make a significant contribution to solution of the U.S. energy problem over both the short and long range. This will be achieved by simultaneous execution of three general objectives:

a) To broaden the resource availability by development of necessary identification and/or production technology.

b) To develop and prove the necessary systems for reliable, economic utilization of geothermal energy to achieve commercialization in the 1980 's and beyond.

c) To advance the necessary supporting technology by a broad based advanced research and development effort utilizing government, academic, and industrial research capabilities.

In order to carry out these objectives the program is structured into four major catigories: resource appraisal, resource utilization technology, advanced research and technology and envirommental, legal and institutional research. 
3. ERDA:Geothermal Program

\subsection{Program Plan}

The program objectives will be achieved through development and demonstration of economical utilization systems which will include the use of energy from several known types of geothemal resources in experimental utilization facilities.

Each type of resource poses special problems in reservoir locations and analysis, energy conversion and utilization, and environmental impacts. Solutions to these problems are required before bringing the resource to on-line production. Therefore, the design of each facility will be oriented toward providing research and engineering data on both the reservoir and the energy conversion system concurrent with the demonstration of electric power generation and other uses of geothermal heat. Throughout the program, effective technology transfer will be encouraged by ooperative arrangements which will stimulate partial financial support of the program by industry. Further, special attention will be given to the institutional, legal, social, and environmental issues bearing on utilization of each type of resource.

\subsection{Technologies to be Invesitgated}

\subsubsection{Resource Assessment}

Geothermal resources are presently classified by temperature, depth, quantity of available in-situ water and salinity. One of the greatest unknowns facing the greater use of geothemal energy is the size and availability of resources. 
The resources can be characterized accurately only by physical penetration (drilling). This is true of other resource exploitation industries where the known discovered supply, or "reserve", is always small compared to the lessknown "resources". which are usually estimated indirectly by a variety of methods and varying degrees of confidence. Industry's "reserves" seldom represent more than a few years supply, and assurance of continued operation usually depends on confidence generated by experience and frequent revision of resource estimates.

The geothermal industry mist operate on a similar basis. The "resources" based on surface emanation and drill hole measurements will always be relatively small, and the possible or probable size of reservoir volumes of specific character ranges must be estimated fram indirect evidence. Such evidence is presently available from a variety of geophysical and geochemical survey methods, and there is much promise for the development of improved and new methods.

Present methods of exploring and assessing geothermal deposits are largely adapted from the petroleum and mining industries. In many cases these require modification for evaluating the special characteristics of geothermal deposits, i.e., high temperature, permeability, salinity of fluids. Accordingly, opportunities are favorable for new innovative theory and technology. Especially promising are integrated multi-disciplinary efforts involving different geophysical, geochemical, geologic, and hydrologic approaches, with each supplying useful data and constraints. 
3

Within the geothermal industry, efforts to date have been focused on selected. "high-grade" resources, regarded as usable at present costs and technology. However, the great potential for geothermal energy utilization lies in the lower grade resources not usable under present conditions. New technology is required for discovering and evaluating resources and for solving physical, chemical, and environmental control problems. Except for a limited number of large energy companies, private investment in costly ventures of uncertain value will likely be avoided. In a new industry where rapid technological advances are urgently required for the national good, Federal involvement is important, especialiy in long-term research, to develop the necessary technology and to make it immediately available to the entire industry.

\subsubsection{Resource Utilization Technology}

Major advances in the production of electric power from geothermal energy will occur by reducing technical and economic uncertainties coiverning the utilization of more abundant lower-grade geothemal resources in an environmentally acceptable manner. To reduce these uncertainties the resource utilization program is directed at advancing the technology that is unique to each resource type. This will be accomplished by the construction of experimental facilities of relatively advanced design, and the establishment of projects to further non-electric uses of geothermal heat.

Higher-temperature geothenmal resources using natural dry steam are presently being developed commercially, with known technologies. However, only limited use is being made of the high temperature/low salinity convective 
system. Power plants using steam flashed fram this resource are in operation in New Zealand, Mexico and Japan, but these installations

- have not been subjected to the enviromental standards which must be met for systems to be developed in the United States. Sone technology exists for the utilization of lower-tenperature convective resources, primarily for space heating. To date no plants have been constructed for the production of electric power from lower temperature convective, geopressured, and hot dry rock resources.

Federal involvement is needed to accelerate private sector cammercial production of geothermal resources, through construction and operation of pilot plants and experimental facilities. These facilities will provide for test bed evaluations of components, reservoir management, training of personnel in field operations and prampt transfer of new technology to industry.

\subsubsection{Advanced Research and Technology}

The program would investigate a variety of problem areas which now inhibit commercial utilization of geothermal energy in the United States. Among these are drilling in hard or fragnented rock, especially where high-velocity flows of geothermal fluids are encountered; well completion, particularly where fracturing of rock is needed to stimulate fluid flow or permit recovery of its contained heat; availability of materials and equipment suitable for handling and extracting hot, corrosive fluids from wet 
geothermal reservoirs; need for systems for efficientlv convertina aeothermal heat into electricity and other useful products: availability of practical methods for monitoring and controlling emissions and wastes; and need for improved reservoir engineering and management techniques. 3.2.4 Environmental Legal, and Institutional Research Research conducted under this subprogram will help establish the factual basis for evaluations of and solutions to: (1) waste disposal problems; (2) environmental impacts of all types; and (3) legal and institutional problems. Development of geothermal energy is being delayed by uncertainties regarding the impact of operations on the local environment and by legal and regulatory constraints. Several of the impacts (e.g., biological effects of gaseous and chemical components of geothermal steam and gases, subsidence, induced seismic activity, and land use) must be fully understood before largescale private sector production can take place.

Arising in part from environmental uncertainties but also from the early stage of technological development, the legal-economic framework for private sector geothermal exploitation poses many undertainties. Policy and regulatory questions (e.g., land use policy, leasing of Federal lands, and tax treatment of geothermal reserves) must be resolved at Federal, state, and local levels.

The requisite background in earth sciences, environmental sciences, and social sciences is at an advanoed stage of development in the U.S. However, only a limited amount of this knowledge has been applied to environmental and related 
problems of geothennal energy development. Two relevant studies supported by NSF are presently being conducted to enlarge the knowledge base. They are: (1) Technology Assessment of Geothermal Energy Resource Development by the Futures Group of Glastonburg, Conn.; and (2) Legal and Economic Aspects of Geothermal Development by the University of Califomia (Berkeley). In addition the Geological Survey has been engaged in gathering environmental baseline data, such as seismicity and subsidence of geothemal areas, to be compared with data ollected during field development.

The Federal Government is in a unique position to conduct the necessary objective research on which the private and public sector can base policy and investment decisions, because the private sector does not possess an institution to address the wide range of inhibiting policies promulgated at Federal, State and local levels of government.

\subsection{Timing and Pace of Development}

The amount of electricity to be provided by geothermal resources in 1985 and 1990 will be quite dependent on decisions reganding the scope of research to be conducted over the immediate future. Concurrent activity should replace the traditional sequential developments as much as possible if the tasks are to be completed in a reasonable time period. These tasks range from resource identification to operational use. For utility companies who are the principal users of geothermal energy, and extraction companies who are the traditional 
suppliers of fuels, their decisions involve such considerations as: expected reservoir lifetime; cost; environmental considerations; return on investment; and projected availability of competitive fuels. The rate at which growth will occur depends on the speed with which these factors can be proven to be favorable for geothermal development.

Once the resource base has been delineated and initial work has raised private sector confidenoe in economic and resource reliability forecasts, the users are expected to develop the resource. The ERDA Program is designed to provide a means to reach the "take-off points" - a time in the evolution of geothermal energy research when the price and technological, political, economic, institutional, and legal factors are in perspective and growth decisions can be fostered. 
4. Program Implementation Plan

Achievement of high levels of commercial production is dependent upon early and close involvement of the private sector during the experimental pilot plant phase. Private sector involvement in the ERDA Ceothemal Program will be acoomplished through the use of the following management approaches:

a) The govermment, thru its National Laboratories or by direct contractual arrangements will work in cooperative ventures with industrial firms and other non-federal organizations to develop utilization systems and components, and provide supporting R\&D for industrial developments. Technical and administrative management control will remain with ERDA and the National Iaboratories. This management approach will develop a technical and administrative capability which will also serve industry during later commercial utilization phases.

b) Cost sharing arrangements with industry, industrial associations, and other non-federal entities will be undertaken for the dual purpose of reducing the Government's cost and enoouraging early participation by the private sector.

Through the use of solicitations, funds will be made to universities, industry, non-profit organizations and National Laboratories teams to oonduct research projects. Unsolicited proposals from these organizations will continue to be enoouraged. 
The Interagency Panel for Geothermal Energy Research which was established in mid-1975 to provide a mechanism for coordination of Federal agencies programs also provides a mechanism for the agencies to jointly assess programs designed to overcome private sector reluctance to exploit geothermal resources. In addition, it is vital to the Federal geothermal effort to establish close ties and information exchange with industry. The principal vehicle for acomplishing this cooperation will be through the operation of a Geothemal Industry Liaison Group which has been established through action of the Interagency Panel.

This Liaison Gromp will be effective in advising the government regarding programs, providing the Interagency Panel with industry perspectives on the problems inhibiting geothermal exploitation, identifying problems relating to industrial participation, and providing the means by which the Panel can inform inaustry of the status of on-going programs. It will also serve as a means for the dissemination of research results for rapid commercial utilization.

The group will include representatives fran electric utilities, resource extraction industries, supply and service industries, agriculture and mining, financial institutions and state and local governments.

In addition to scientists and engineers, it will include persons concerned with marketing matters to insure that the widest range of private sector attitudes and perspectives are available to the Interagency Panel. 


\subsection{Research and Development Program}

The ERDA geothermal energy program provides for pilot plant projects corresponding to the types of geothemal resources requiring technological development for practical exploitation.

In addition to the pilot plant program, a number of broadly applicable technological areas will be identified in specific R\&D programs both to support projects and to provide a technological base for comercial development.

\subsection{Detailed Program Objectives}

Aspects of the geothermal program, which are directed at strengthening and broadening the scientific and technological base of geothemal industries include: resource assessment, resource utilization, advanced research and technology and environmental, legal and institutional research.

\subsubsection{Resource Assessment}

This program will investigate and appraise all types of geothermal resources, including the identification of potential sites for industry exploration and development. 
In conjunction with the U.S. Geological Survey, this program will improve practical operating geophysical, geochemical, geological and hydrological techniques necessary for characterizing geothermal resources.

It will also develop better methods for predicting the power potential and longevity of geothermal reservoirs including use of mathematical modeling of reservoirs and computer-based calculational techniques.

Estimates will be made of reserves and resources, and industry will be monitored to assess company activities, exploration success, production, technology development and future market trends. This aspect of the resource appraisal program will be conducted by ERDA at a market level.

\subsubsection{Resource Utilization Projects}

These projects will provide an operational, technological, and economic data base sufficient to demonstrate the practicality of achieving commercial production of $30,000 \mathrm{MNe}$ by 1985 , and commercial non-electrical uses of geothermal energy in an environmentally acceptable form.

The objectives of these projects are: (1) to prove economic geothermal production systems and omponents meeting environmental standards, (2) to construct four pilot plants of 10 Me power eact, (3) to gain operational experience in reservoir engineering and mangement, (4) to gain operational experience with geothemal power plants and detemine the operating characteristics and potential of geothemal reservoirs, (5) to provide 
1

experimental test beds for component testing and evaluation, (6) to involve engineers, analysts, technicians and managers from industry leading to early industrial exploitation of advanced geothermal resources and (7) to develop a cadre of trained geothermal engineers and technicians.

The following pilot plants are planned for ocmpletion prior to 1980 :

\section{Resource Type}

1) High-Temperature convective (above $180^{\circ} \mathrm{C}$ )

a) Iow-Salinity $(20,000$ PPM or less)

b) High-Salinity (over 100,000 PPM)

2) Moderate Temperature Convective-Low salinity (below $180^{\circ} \mathrm{C}$ )

3) Moderate Temperature Convective-low salinity (below $180^{\circ} \mathrm{C}$ )
1978 Northern Nevada

1979

1979

Southern Idaho

1978
Proposed

Iocation

The pilot plants are associated with those resources which can be developed

in the near future, based upon availability of sufficient technology to

implement these programs. In addition, developments will be pursued in other

high-risk areas, such as geopressured, hot dry rock and near-normal gradient

resources, pilot plants for utilization of these resources also will be

planned, if appropriate, as these research programs develop. 


\subsubsection{Advanced Research and Technology}

This program will help to resolve major technical problems inhibiting commercial utilization of geothermal resources in the U.S.

The objectives of this program are: (1) to develop effective, efficient drilling methods to operate at elevated temperatures, (2) to develop reliable predictive methods and control techniques for the production of geothermal fluids from reservoirs (3) to exploit new concepts for fracturing rock to permit recovery of contained heat, (4) to improve equipment and technology for the extraction of geothermal energy from reservoirs, (5) to develop inproved methods for converting geothermal energy and associated fluids to useful products, (6) to develop improved methods for monitoring and controlling emissions and waste from geothermal utilization facilities.

\subsubsection{Environmental, Iegal and Institutional Research}

This program is directed towand encouragement of the commercial development of geothermal resources by providing the technical base for evaluations, options, and decisions regarding the enviromental, legal and institutional issues associated with resource utilization.

These studies will evaluate waste disposal technology and surface and sub-surface envirommental effects of geothermal development. 
They will also aid in identifying social, legal and economic problems associated with geothermal development, both locally and regionally, for policy development, and in providing socio-economic framework for the commercial utilization of geothermal resources.

\subsection{Detailed Program, Quantitative Schedules and Milestones}

Figure I shows the schedule and milestones for the four pilot plants that are planned through 1979. Schedules for other pilot plants will be developed as appropriate as additional resource projects are defined.

\subsubsection{Resource Assessment.}

Identification of resources to supply the high temperature low salinity and medium temperature low salinity projects is needed during FY 1975 , with complete evaluation in FY 1976. Resource identification for the salton Trough high temperature-high salinity project is needed in FY 1977. Identification and appraisal of resources to support the geopressured fluid, near-normal gradient and other projects are in the planning stages. Two potential sites for the ory hot rock resource have been selected and evaluation will probably be completed during FY 1976.

The accumulation of data and a running estimate of geothermal resources and local and national reserves are paramount in order to assess sufficiency and economic availability of resources at the time needed. Whereas the United States Geological Survey will thoroughly investigate all the nation's geothermal resources and the methods for identifying them, that investigation will be broad and will require a significant time period. ERDA's evaluation, which will supplement the USGS program, is designed to be immediately responsive to the needs of specific demonstration pilot plants. 
Moderate Temperature Iow Salinity

(Shallow Rift Valley)

Moderate TemperatureLow Salinity

(Sedimentary Basin)

High TemperatureHigh Salinity

High TemperatureIow Salinity
RESOURCE UTIIIZATION PROAECTS

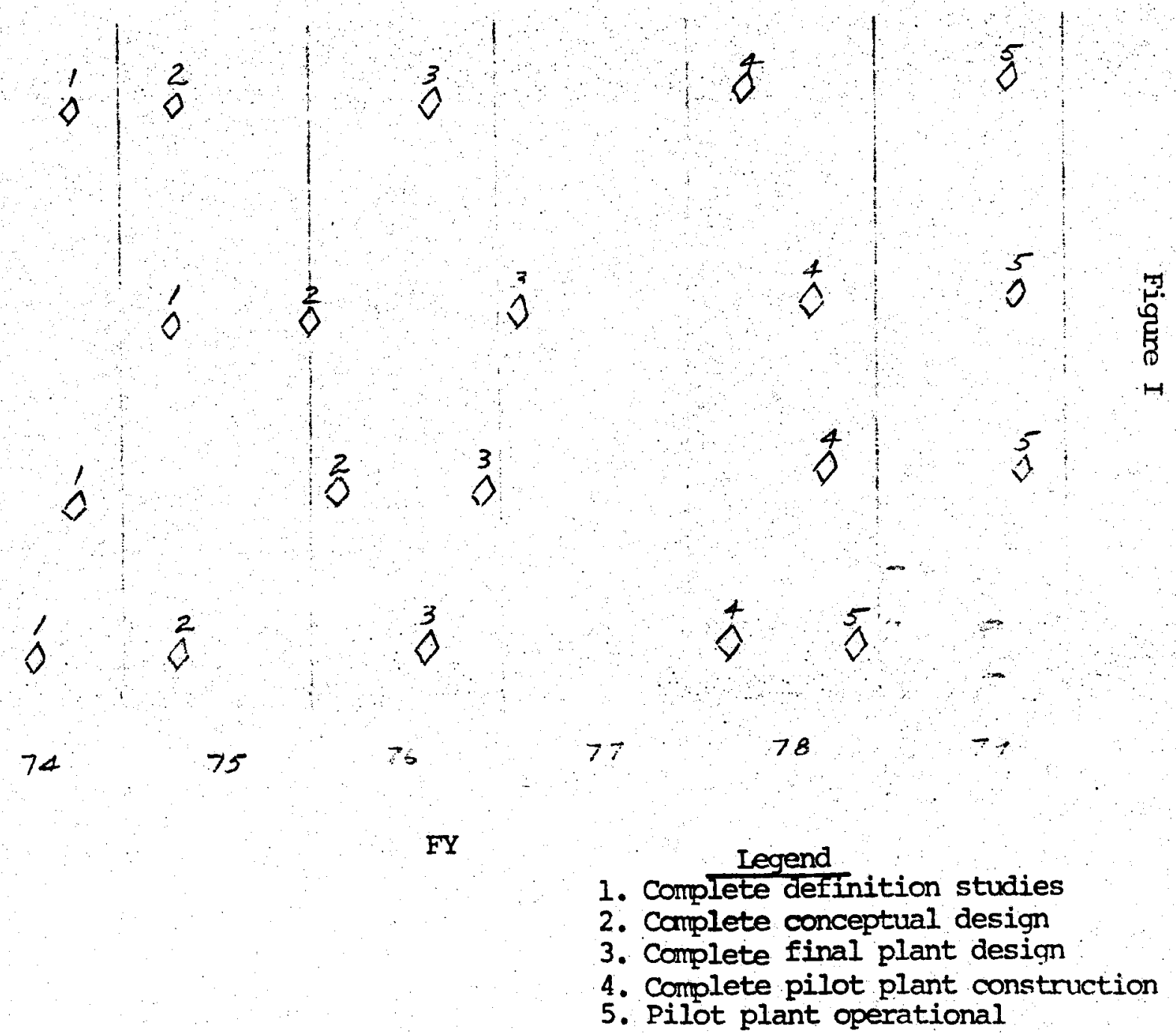


Current information will be maintained on industry activities, progress, and resource acquisition. Such information is needed for reserve estimates and analyses which are vital to the planning of federal programs.

\subsubsection{Resource Utilization}

Components of the resource utilization program are described below: 1

4.3.2.1 High Temperature Low Salinity Resource

The principal objective of this project is to demonstrate that this resource (brine temperature $180^{\circ} \mathrm{C}-210^{\circ} \mathrm{C}$ and dissolved solids less than 20,000 PPM) can be utilized to produce electric power economically and in a manner compatible with the environment. The project effort is divided into three main categories namely, site selection and reservoir delíneation; design and construction of a $10 \mathrm{MN}$ field experimental facility; and a research program to acquire knowledge on geothermal energy systems of this type. Initial field work which started in FY 74 , has been centered in northcentral Nevada.

Geophysical field surveys will be completed in FY 75 and heat flow measurements will be used to confirm the geophysical field survey data. Acceptable tr'st well characteristics will establish the site, and production well drilling will start in FY 76. When the production and reinjection wells are completed in FY 77, a downhole pump and reinjection test program will be initiated. This test program will be used to improve downhole pump reliability and to provide data on the operating characteristics of the reservoir system. 
The geophysical research program, which will be continued through FY 79, will develop reservoir delineation techniques to a point where accurate estimates can be made of the total energy content of individual reservoirs.

The experimental facility will demonstrate electric power production and supply detailed information on plant and reservoir operation characteristics. The plant will be designed to permit facility operation in a flexible manner to provide experimental data on geothermal fluid management, component performance, and engineering aspects of the power cycle. Plant design will also provide easy access to all equipment, so that new components can be interchanged with existing ones, allowing comprehensive testing under field conditions. The overall plant design will be oriented toward eventual remote operation. As an alternative to oonstruction of a pilot power plant under ERDA sponsorship, consideration is being given to merely providing technical support for one or more of the proposed industrially-sponsored demonstration plants, either through laboratory R\&D studies, construction and operation of a field test facility or both. The final decision on this alternative will depend in large part upon the rate of implementation of industrial plans.

\subsubsection{High Temperature-High Salinity Resource}

The purpose of this program is to develop the necessary technology for economic recovery and conversion of the themal energy stored in the high temperature $\left(250^{\circ} \mathrm{C}\right)$ high saline brines $(20 \%$ by weight of dissolved solids). Known deposits of such brines underly the Imperial Valley of California. Compared to other hot water systems, the geology and geochemistry of this resource is relatively well known, and it is located close to large population areas. 
A novel power cycle being developed for this resource consists of expanding the total hot brine-steam mixture through nozzles, This converts the themal energy in the wellhead product into kinetic energy of motion in the form of high velocity streams of the mixture. These jets are used to drive a specially designed, single stage impulse turbine. This concept, called Total Flow, offers the potential advantage of higher conversion efficiency, and design flexibility to facilitate control of scaling. The concept, which ultimately can also be applied to lower temperature resources, requires system as well as component development. In support of this technical development it is proposed to construct a facility which will consist of wells for production and for injection, and instrumented field laboratories located in two separate areas. These field laboratories will be available to researchers involved in development if advanced technology for extraction, utilization, and energy conversion relevant to brine exploitation. This will provide continuous access to flowing wells and will provide realistic test data under field conditions for brine chemistry research, material evaluation and performance, and evaluation of energy conversion devices.

\subsubsection{Moderate Temperature-Low Salinity}

Medium temperature geothemal fluid is generally considered to be below that currently attractive for electrical power production. 
Though the magnitude of this resource is not precisely known, it is probably greater than that available from the high temperature (above $180^{\circ} \mathrm{C}$ ) geothermal resources. However, the medium temperature potential for supplying a significant fraction of the nation's future energy needs depends on the development of economical and efficient means of converting this energy into useful forms. The twofold approach will be to:

1) Develop economic means of producing electrical eneray fran such a rescirce and determine the lower economical temperature limit. 2)Utilize the enthalpy directly for such applications as process heat, space heating and cooling, and related agricultural uses, and examine the economics of a total energy use concept. (See Non-Electric Utilization Plan.)

In order to assess the potential of several water-daminated, convective, moderate-temperature geothermal sites, the ERDA program involves research and development leading to the design, construction and operation of two pilot plants of approximately $10 \mathrm{MN}$ capacity. In addition to development of systems for the generation of electrical power from moderate temperature resources, an important objective of this project will be to develop the technology needed to recharge a reservoir by reinjection of geothermal fluids. The program will also require power cycle design studies for multiple flash systems as well as binary fluid power cycle systems. In addition, basic geology, hydrology and geophysics studies will be completed prior to locating plant sites. 


\subsubsection{Sedimentary Basins (Geopressured Resourc)}

The purpose of this program is to carry out the necessary development work leading to methods for economic recovery and conversion of the energy stored in geopressured deposits. Known deposits underly the Gulf coast region of the United States, where there may be enough energy stored in the form or heat and pressure to supply millions of megawatt-years of electric energy. Also, it is estimated that significant quantities of methane are associated with these water deposits.

The geopressured resource development program will initially emphasize resource and reservir assessment activities. Conversion of the energy to electricity may utilize the higher efficiency total flow concept, once developed. The first task will be to carry out a general feasibility study including sufficient field work to better define the nature and extent of exploitable reservoirs. Depending on the results of this study, a long-term development program will be formulated.

\subsubsection{Hot Dry Rock}

Hot dry rock in the earth's crust may constitute the largest and most broadly distributed reservoir of immediately usable energy that is accessible to man. The first method to be investigated in this project involves drilling two adjacent hicles into the hot rock, connecting them by means of a very large crack system made by hydraulic fracturing, and circulating pressurized water through the crack to extract heat fram the rock to bring the heat to the surface of the earth. 
Two regions which appear suitable for development of such a system have been identified, one on the Jemez Plateau of north-central New Mexico, and the other near Marysville in the westem part of Montana.

At the New Mexico site, a well has been drilled to $6,700 \mathrm{ft} . \mathrm{and}$ hydraulic fracturing experiments have been successfully completed at that depth. After deepening of this well to $9,000 \mathrm{ft}$. or more, to obtain a hiaher temperature, additional hydraulic fracturing tests will be performed. A circulation system will be established in the fractured nock reservoir to enable fluid circulation tests to be conducted to prove the feasibility of utilizing hot dry rock as a source of energy.

At the Montana site, a well has been drilled to approximately $6,000 \mathrm{ft}$. and attempts are being made to measure the rock temperatures at that depth and to determine the water content of the reservair.

When the circulation system has proved to be feasible, surface experimental facilities will be constructed to demonstrate that heat from this resource can be utilized for the production of power.

\subsubsection{Near-Normal Gradient Resources}

The primary abject of the near-normal gradient geothermal resource program is to study the extension of the hot dry rock geothermal resource extraction technology to the eastern and mid-continent united States to regions of near-nomal thermal gradients. The study will be followed by selection of potential sites for a suitable demonstration site. 
Initially, the project will demonstrate an energy extraction system suitable. for use in relatively impermeable rocks such as the granites of the Northeastern United States. It will then lead to demonstration of energy extraction sufficient to support a 10-megawatt (electrical) power plant, or for heating applications.

\subsubsection{Non-Electric Uses}

While high temperature geothermal water deposits are probably best suited for electric power production, there are also large resources of lower temperature waters located over wide regions of the U.S. Use of these low temperature waters for non-electrical purposes should be considered both as a fo isil fuel conservation measure and as an altemate energy resouroe. The nonelectrical uses program will enhance the development of experimental or demonstration systems, and prove their technical and economic feasibility.

In view of the urgency to achieve enengy independence, this program will establish feasibility in FY 76 with demonstration following as soon as practical. Comprising residential and commercial, agricultural and industrial processes, the non-electric utilization program will onsist of an assessment of geothermal resources, including low temperature hot springs, possible uses of the resource, and the technology required for reovery and utilization. This investigation will result in development of necessary technology leading to system designs and components for demonstration or experimental facilities. 
The technology to be assessed or developed depends upon features of the specific resource being considered and the possible applications in that locality. In general, areas of technology development could include: themal energy transport and storage; heat exchange systems; fluid/minera] separators; low temperature turbines; and heat pumps. In addition there would be areas of development peculiar to the specific applications, including interactions with other energy systems.

The non-electrical uses program is expected to lead to demonstration projects in the following basic activities.

1. Application to supply of heat to existing cities and industry - Fmphas,is will be on stimulating the use of geothermal energy, in areas already populated and/or industrialized, and dependent on fossil energy sources. Hence, the purpose is to provide an alternate energy source.

2. Utilization of geothermal energy for development of new cammuities and/or industries - The emphasis will be to locate, identify, characterize and develop geothenmal resources which can be utilized by industrial/agricultural processes to stimulate development of new commities and industries at locations where geothemal energy is available.

3. Development of remote communities which are energy depressed - Through development of local industries, this activity is intended to provide a $i$ general upgrading in the standard of living of small commuities in remote 
areas which are energy depressed and which may be dependent on deliveries of fuel at very high transportation costs.

In keeping with the strategy of short-term govemment involvement to encourage the private sector, emphasis will be placed on funding industrial-federal and state and local-federal joint projects.

$\lambda$ 


\subsubsection{Advanced Research and Technology}

The purpose of the Advanced Research and Technology Program is to carry out the necessary research and development on devices and systems, leading to an overall advancement in geothemal energy development.

- Although same of this work will be done within, and as an integral part of the resource utilization projects, the programs in advanced research and technology will be directed toward a broader, longer-range goal, This will produce advancements in design of succeeding generations of energy systems beyond the initial demonstration systems. An activity may even result in development of a concept of sufficient breadth to justify creation of a new utilization program leading to a demanstration project.

\subsubsection{Advanced Drilling Technology}

Well drilling represents excavation, hole support, and debris removal. In oil or gas wells, excavation is accamplished with mechanical rotary bits with the help of the circulating fluid or mad. Temporary support and debris removal are accomplished with the drilling ma subsystem, with final support being provided by cemented steel casings. The circulation subsystem is a key element which can substantially affect the cost of producing a wel1. An evaluation of drilling requirements for geothermal energy indicates that significant developments are desirable and even necessary in the following areas: 

a) reduction in cost of drilling wells
b) improvement in rotary bit life and bearing lubrication systems,
c) improvement in drilling mas and cements for high temperature applications,
d) development of directional control drilling equipment,
e) development of advanced drilling techniques and devices,
f) improvement in downhole well logging and coring equipment,
g) improvements in hole stabilization techniques

The advanced research and technology projects under ERDA will include programs to advance the state of the art in those areas.

\subsubsection{Fluid Handling}

Fluid handling for above-wellhead applications includes all surface systems exclusive of the energy conversion devices. Because of the special problens created by dissolved solids and/or gases, high temperature pressures and envirormental constraints, special attention must be given to equipment selection and design.

For high salinity brines, fluid handling systems will include modification or redesign of separators, collection systems, cooling and condensing apparatus, and power plant control systems. For the geopressured waters, high pressures may require special developments in regulators and particularly 
separators to remove the associated methane. Although the salinities in the geopressured waters may be relatively low, the combination with high pressures may require investigations into material behavior and selection in terms of erosion and corrosion resistance. In addition, brine management methods for scale control or prevention, brine disposal, and environmental impact assessment may require special developments in instrumentation and/or devices for fluid handling.

\subsubsection{Advanced Energy Conversion Technology}

Each utilization program includes development and design of conversion methods unique to the particular resource under study. However, advanced work in energy conversion will be pursued to supplement the ongoing programmatic efforts.

Energy conversion research will be divided into power production systems, new conversion devices, and basic research into fluid and material properties. In the first category, methods for generalized studies of. power cycles, optimization, and overall system analyses incluaing concept definitions will be developed. Much of this work will necessarily be done directly in the utilization program, but special expertise will be obtained from industry and the academic sectors. 
The second and third categories will be the main thrust since this effort will lead to new concepts for energy conversion. This will require development research on new concepts for turbine design and possibly completely new approaches involving direct conversion systems. Coupled with this, research will be needed to measure thermodymamic properties of geothermal brines and secondary fluids for binary cycle systems, evaluate materials and investigate two-phase flow phenomenology.

\subsubsection{Reservoir Analysis}

Through reservoir analysis, mathematical models to be used in the numerical computation of the flow of energy and fluid in genthermal reservoir systens will be developed. It will be necessary to study the effect of heat extraction on temperature and pressure distributions within the producing reservoir, with and without reinjection. Ultimately, this research is aimed at providing methods of determining the orfentation and spacing of production and reinjection wells, the optimm rate of energy removal, and the useful life of a geothermal reservoir.

\subsubsection{Extraction and Reinjection}

Extraction technology requires the development of reliable downhole pumps in liquid dominated reservoir systems where a bi-fluid energy conversion rycle is utilized. The purpose of the pump is twofold: to produce the fluid in the well bore and to maintain the well fluid at a pressure greater than the saturation pressure corresponding to the fluid temperature to avoid flashing to steam. 


\subsubsection{Economics, Cost/Benefit and Systems Analysis}

Through econamic modeling of geothermal systems, the unit cost of electricity produced from each geothermal resource type will be determined. In addition the model will enable projections of the demand for geothermal power in campetition with other energy sources.

Utilizing detailed cost analysis of materials, reservoir exploration and development, power plant construction and operations, the model will be used as a base for detailed sensitivity analysis, which will include determination of the relative effect on power costs of each important factor of production.

A concurrent supply and demand analysis of critical resources used in geothermal power exploration and development will include forecasts of instailed capacity, potential savings in alternative fuels, and potential effects on balance of payments. The analysis will project capital, material, land and labor requirements for the development of geothermal power as well as potential requirements and availability of cooling water, drilling rigs, turbines, bore hole casings and other significant factors. The study will identify promising areas for technological development and define areas of high uncertainty or risk in need of further research and developrant. The validity of the model will be checked with cost and operating data fram existing geothermal plants, both within and outside the U.S. 
Following completion of the sensitivity analysis, a modified model capable of selecting the minimu cost design for a specified set of resource and economic characteristics will be developed. This model will also have the capability to project costs from small prototype plants to large power industry.

Using a framework to analyze the potential benefits of proposed research programs, the economic model will provide the base for evaluating the incentives for developing new geothermal technology.

The systems anaiysis approach will be used to better define interrelationships of program components and to re-evaluate decision points for orderly management of the total geothermal program. 


\subsection{Interfaces with Other Agencies}

The national geothermal energy research program involves the activities of several agencies, specifically, ERDA, Department of the Interior, (the U.S. Geological Survey, the Bureau of Reclamation and the Bureau of Mines) and NASA in research programs aimed at developing both electric and non-electric

uses (e.g., desalination, mineral recovery and industrial processes) of geothemal energy. Other Federal agencies involved in the program include the Environmental Protection Agency and the Council on Enviranmental Quality to assist in formulating environmental considerations, the Federal Power Commission to assist in addressing regulatory (i.e., rate base and rate structure) matters, and the Bureau of Land Management to address lease mitters. An Interagency Geothermal Energy Research Panel has been established to provide a mechanism for coordinating the geothermal programs of Federal agencies. While Panel members continue to be responsive to their individual agencies for the execution of assigned geothermal activities, the Panel serves as the focal point to ensure that all Federal efforts are properly integrated and coordinated.

The U.S. Geological Survey, a major contributor, with ERDA, toward achieving the goals of the ERDA geothermal program, supports a program of work which can be classified into six broad categories:

1. Iocation of geothermal target areas and estimation of national resources.

2. Science and technology for detemining the energy potential of specific geothermal reservoirs. 
3. Geothermal exploration technology.

4. Energy potential of deep parts of geothemal reservoirs.

5. Geochemical control of reservoir permeability. :

6. Environmental impact of geothermal extraction.

Under these broad categories of work, the USGS undertakes studies of regiohal geothermal evaluation, and geologic, geophysical, geochemical and hydrologic investigations applicable to the various types of resources of interest in the ERDA program.

The funding for the USGS in support of the total Federal geothermal program is a major part of the Department of Interior's geothermal energy effort, which is shown in Figure II with the funding level for ERDA.

As noted in prior sections of this document, an objective of the EPDA Program is the early utilization of research results by industry so that oomercial production of electricity can be achieved. In order to realize this objective it is essential that industry - including producers of energy as well as public utilities - be involved in the program and kept ontinuously informed on progress and results. Accordingly, Industry, in a team effort with universities and national laboratories, will be heavily involved in project management, and as prime contractors and key subcontractors. In addition, close cooperation will be maintained with the Electric Power Research Institute to integrate the results of ERDA programs into the entire utility industry. 
( $\$$ in millions)

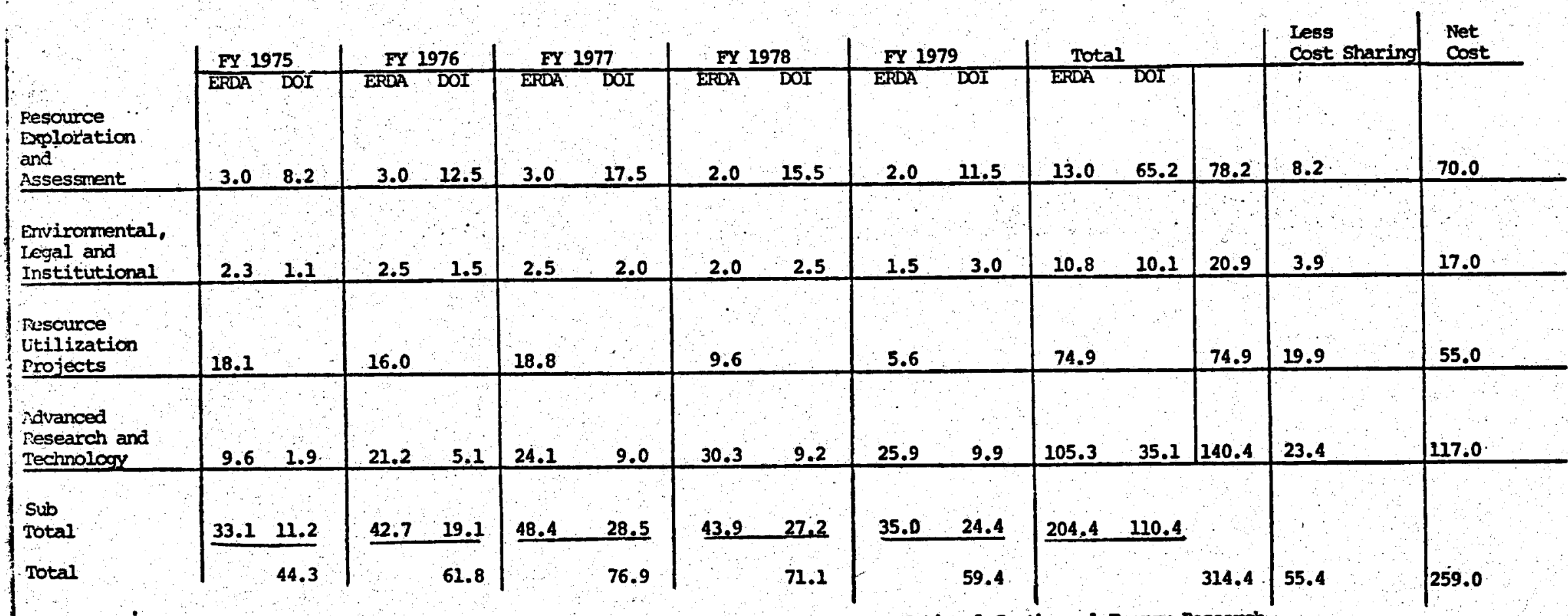

*EROA budget combines ADC and NSF budgets, as presented in ONB repont on National Geothenmal Enengy Research Programs, July 31, 1974.

* In the absence of specific guidance on transfer of funds from NSF to EROA is has been assumed for purposes of this report that all NFF geothermal work would be administered by ERDA. 